\title{
The callipyge mutation and other genes that affect muscle hypertrophy in sheep
}

\author{
Noelle E. COCKETT ${ }^{\mathrm{a} *}$, Maria A. SMIT ${ }^{\mathrm{a}}$, Christopher A. BIDWELL ${ }^{\mathrm{b}}$, \\ Karin SEGERS ${ }^{\mathrm{c}}$, Tracy L. HADFIELD ${ }^{\mathrm{a}}$, Gary D. SNOWDER ${ }^{\mathrm{d}}$, \\ Michel GEORGES ${ }^{\mathrm{c}}$, Carole CHARLIER ${ }^{\mathrm{c}}$ \\ ${ }^{a}$ Department of Animal, Dairy and Veterinary Sciences, Utah State University, \\ Logan, UT 84322, USA \\ ${ }^{\mathrm{b}}$ Department of Animal Sciences, Purdue University, West Lafayette, IN 47907, USA \\ ${ }^{\mathrm{c}}$ Department of Genetics, Faculty of Veterinary Medicine, University of Liège, \\ 4000 Liège, Belgium \\ d USDA/ARS U.S. Meat Animal Research Center, Clay Center, NE 68933, USA
}

(Accepted: 19 July 2004)

\begin{abstract}
Genetic strategies to improve the profitability of sheep operations have generally focused on traits for reproduction. However, natural mutations exist in sheep that affect muscle growth and development, and the exploitation of these mutations in breeding strategies has the potential to significantly improve lamb-meat quality. The best-documented mutation for muscle development in sheep is callipyge $(C L P G)$, which causes a postnatal muscle hypertrophy that is localized to the pelvic limbs and loin. Enhanced skeletal muscle growth is also observed in animals with the Carwell (or rib-eye muscling) mutation, and a double-muscling phenotype has been documented for animals of the Texel sheep breed. However, the actual mutations responsible for these muscular hypertrophy phenotypes in sheep have yet to be identified, and further characterization of the genetic basis for these phenotypes will provide insight into the biological control of muscle growth and body composition.
\end{abstract}

sheep / muscle / hypertrophy / callipyge / mutation

\section{INTRODUCTION}

The trait with the greatest financial impact on sheep production is the number of lambs weaned per ewe [7]. Correspondingly, breeding schemes for improved lamb-meat production have focused on selecting animals with superior reproductive capacities, and studies directed at the genetic improvement of sheep have been primarily concerned with reproductive traits

${ }^{*}$ Corresponding author: noelle.cockett@usu.edu 
(for review, see [45]). From a producer's standpoint, a greater number of lambs result in a higher profit margin. Thus, quantity rather than quality has been the main focus of the sheep community for decades.

Although the importance of improving lamb carcass composition has been recognized since the 1950's (reviewed in [60]), the sheep industry, particularly in the United States, has made little progress toward improving the carcass merit of slaughter lambs. In fact, the only alteration to carcass composition appears to be that from the butcher's knife; Tatum et al. [56] reported that extensive fat trimming occurs at the retail level. This excess of fat accumulation is caused by the over-finishing of lambs, which has been widely practiced in recent years to increase profitability. In the United States, the average live weight of slaughter lambs has jumped from 104 pounds in 1975 to 141 pounds in 2002 [28]. However, more than half of all lamb carcasses in the United States currently exceed the recommendations for backfat thickness put forth by the American Sheep Industry Association (ASI), and less than one-third of market lambs meet the criteria for leanness and muscling specified by the ASI's Certified Fresh American Lamb ${ }^{\mathrm{TM}}$ program [3].

Recently, efforts to improve carcass merit in sheep have been prompted by studies on consumer acceptability of lambs $[18,27]$, which indicate that lambs harvested at a younger age are preferred by consumers to over-finished lambs. Health-conscious consumers favor lamb cuts with less fat, but consumers also prefer larger chops, since they look for value in their money. Thus, there is considerable interest in identifying ways to effectively manage sheep-meat operations so as to increase the lean content and decrease the fat content of lamb products.

Unfortunately, producers are generally not financially rewarded for improved carcass quality at the present time. However, strategies to increase lean production and decrease fat deposition result in improved feed conversion efficiency. Among the benefits to the producer of enhanced feed conversion efficiency include lower production costs, higher product yields, less nitrogenous-waste excretion into the environment, and decreased grazing pressure. Achievement of increased feed conversion efficiency can be attained through the use of hormonal growth promoters, transgenic animals, nutritional strategies, choice of terminal sire breed, and marketing lambs at appropriate slaughter weights (reviewed in [3,52]). However, the banning of hormonal growth promoters by the European Union, the problems with gene expression in transgenic animals, and the limited advance of nutritional studies in sheep have restricted the incorporation of these strategies into production schemes. 
The most promising strategy for manipulating and improving carcass composition in sheep, and one that is likely to gain widespread public acceptance, is genetic selection. Within- and between-breed variation in meat coloration, marbling, fatty acid profile, and protein concentration have been documented in sheep (reviewed in [57]). However, until recently, carcass traits could only be measured on dead animals, and this has hampered genetic selection for improved carcass quality. The development of several live-animal measurement techniques (reviewed in [4]) has greatly facilitated the identification of specific carcass traits that respond to genetic selection in sheep. The identification and characterization of major genes and quantitative trait loci (QTL) that influence fat and lean deposition will pave the way for improved lamb-meat products in the future.

\section{LOCI RESPONSIBLE FOR CARCASS QUALITY IN SHEEP}

To date, nine distinct loci have been identified that influence carcass composition in sheep (Tab. I). Of these, the three best-known muscle traits in sheep (callipyge, Carwell, and double muscling, respectively) are characterized as a hypertrophy of the myofibers. In contrast to muscle hyperplasia, which is an increase in myocyte number, muscular hypertrophy is an increase in myofiber diameter. However, the actual biological mechanism by which these mutations give rise to muscle enhancement is not yet known. Further characterization of the genes and mutations responsible for muscle hypertrophy in sheep will provide new insight into the control of growth and body composition.

\subsection{The callipyge (CLPG) locus}

The callipyge phenotype in sheep is a muscular hypertrophy that is most pronounced in the muscles of the pelvic limb [26,32]. Muscles from callipygeexpressing lambs enlarge to differing degrees, and not all muscles are affected. In an extensive survey of 19 muscles dissected from the right side of carcasses from normal and callipyge individuals [26], the total weight of excised muscles from the pelvic, torso, and thoracic limbs was greater in callipyge lambs by $42 \%, 50 \%$, and $14 \%$, respectively, than in normally muscled half-sibs. This muscle hypertrophy develops after about three weeks of age [24], so there is no increased risk of dystocia for callipyge lambs.

Callipyge lambs exhibit several desirable production characteristics and meat quality traits. Higher dressing percentages, larger longissimus (loin eye) areas, superior lean composition, and higher leg scores have been documented 
Table I. Genes and QTL affecting carcass composition in sheep.

\begin{tabular}{|c|c|c|c|c|}
\hline Name of phenotype $^{1}$ & Ref. & Breed & Chr. & Description \\
\hline Callipyge & [15] & American Dorset & 18 & $\begin{array}{l}\sim 30 \% \text { increase in muscle mass } \\
\sim 8 \% \text { decrease in fat content } \\
\text { Localized in the hindquarters }\end{array}$ \\
\hline Carwell & $\begin{array}{l}{[47]} \\
{[61]}\end{array}$ & $\begin{array}{l}\text { Australian Poll Dorset } \\
\text { British Texel }\end{array}$ & $\begin{array}{l}18 \\
18\end{array}$ & $\begin{array}{l}\sim 10 \% \text { increase in rib-eye area } \\
\text { Same effect as reported in [47] }\end{array}$ \\
\hline Double Muscling & $\begin{array}{l}{[39]} \\
{[36]} \\
{[8]}\end{array}$ & $\begin{array}{l}\text { Australian Texel } \\
\text { Belgian Texel } \\
\text { New Zealand Texel }\end{array}$ & $\begin{array}{l}\text { n.t. } \\
2 \\
2 \\
2\end{array}$ & $\begin{array}{l}\text { Generalized muscular hypertrophy } \\
\text { Generalized muscular hypertrophy } \\
\text { Generalized muscular hypertrophy }\end{array}$ \\
\hline Other QTL & [62] & British Suffolk & $\begin{array}{l}1 \\
3 \\
18\end{array}$ & $\begin{array}{l}\text { Muscle depth and weight } \\
\text { Fat weight } \\
\text { Weight at } 8 \text { weeks of age }\end{array}$ \\
\hline & [62] & British Texel & $\begin{array}{l}3 \\
4 \\
20\end{array}$ & $\begin{array}{l}\text { Muscle depth and weight } \\
\text { Fat weight } \\
\text { Fat depth }\end{array}$ \\
\hline
\end{tabular}

${ }^{1}$ The causative mutations for the Carwell (rib-eye muscling) and double-muscling phenotypes have not been identified. However, QTL at similar chromosomal locations that correspond to each of these phenotypes have been reported in multiple populations. Confirmation that the same genetic mutation is responsible for the similar phenotypes reported in each of these populations will be possible upon identification of the causative mutations.

${ }^{2}$ Not tested. A generalized muscular hypertrophy that is reminiscent of double muscling in Belgian and New Zealand Texels is also segregating in the Australian population.

for callipyge carcasses $[25,32]$. These superior carcass traits translate into improved yields of wholesale leg, loin, rack, and shoulder from callipyge animals by $11.8 \%, 4.7 \%, 2.5 \%$, and $2.3 \%$, respectively, over normally muscled lambs [9]. In addition, callipyge lambs exhibit superior feed efficiencies and lower daily feed intakes [24], which result in lower production expenses. Therefore, the widespread production of callipyge lamb would have the potential to lower the cost of lamb for consumers and to increase the profitability of the sheep industry. Unfortunately, the stigma associated with callipyge lamb as being unacceptably tough $[32,46,51]$ has limited its production in the United States.

Enlargement of muscles in callipyge-expressing animals is primarily due to myofiber hypertrophy. Histological examination of myofibers [10] in callipyge-responsive versus normal muscles showed that the callipygeresponsive muscles exhibit larger average diameters for the fast-twitch 
oxidative glycolytic (FOG) and fast-twitch glycolytic (FG) muscle fibers and smaller average diameters for the slow-twitch oxidative (SO) fibers. In addition, the percentage of FG fibers is greater and the percentages of SO and FOG fibers are smaller in callipyge-responsive muscles. Thus, myofiber changes in callipyge animals were strongly associated with the FG fibers, the only fiber type that increase in proportion and diameter in the callipyge-responsive muscles. This hypertrophy was evident in 8-week-old but not in 2-week-old lambs [11], thereby supporting gross phenotypic observations of postnatal development of the callipyge.

The callipyge trait in sheep exhibits a novel mode of inheritance termed "polar overdominance" [15]. The only animals that express the callipyge phenotype are the heterozygous offspring who inherit the callipyge (CLPG) mutation from their sire (i.e. the ${ }^{M}{ }^{M} / C L P G^{P}$ genotype, where the superscripts $\mathrm{M}$ and $\mathrm{P}$ refer to the maternal or paternal inheritance of the alleles, respectively). The other three genotypes $\left(+^{M} /+^{P}, C L P G^{M} /+^{P}\right.$, and $\left.C L P G^{M} / C L P G^{P}\right)$ are phenotypically normal. Although hybrid dysgenesis in Drosophila [30] and polar lethality in mice [58] also exhibit parent-of-origindependent and heterozygote-specific phenotypic effects, callipyge in sheep is the only known example of strict polar overdominance reported to date. The polar overdominance model for callipyge in sheep has been confirmed in an independent flock [19], thereby demonstrating that callipyge polar overdominance in sheep represents a truly novel mode of inheritance.

Recently, a decade-long positional cloning effort to identify the CLPG mutation came to fruition with the identification of an A-to-G transition that segregates perfectly with the CLPG allele [20,53]. This polymorphism, which is designated as $S N P^{C L P G}$, lies within a conserved 12-bp motif that is located approximately $33 \mathrm{~kb}$ upstream of the GTL2 gene. The causality of this mutation was strongly supported by our finding that Solid Gold, the founder ram of the callipyge trait, was mosaic for the mutation [53]. We suggested that the $C L P G$ mutation (which corresponds to the $G$ allele of $S N P^{C L P G}$ ) arose during Solid Gold's early embryonic development, thereby rendering him mosaic for $S N P^{C L P G}$ in both somatic and germline tissues.

The $S N P^{C L P G}$ mutation lies within the DLK1-GTL2 imprinted gene cluster on ovine chromosome 18 (OAR18). This imprinted gene cluster contains several paternally expressed protein-coding genes, including BEGAIN [54], DLK1 [31, 49, 55, 65], PEG11 [14], and DIO3 [22, 59, 66], as well as several 
maternally expressed non-coding RNA genes, including GTL2 [44,49, 55, 65], antiPEG11 [14], MEG8 [14], and MIRG [50]. The BEGAIN, DLK1, PEG11, GTL2, antiPEG11, and MEG8 genes have been shown to be expressed and subject to genomic imprinting in ovine skeletal muscle tissues [14,54].

To date, the precise function of $S N P^{C L P G}$ remains elusive. However, a potential function for $S N P^{C L P G}$ has been inferred from studies that examined the expression patterns of genes in the DLK1-GTL2 cluster in animals of the four $C L P G$ genotypes. Northern blot analysis of longissimus muscle-derived RNA has demonstrated that the expression of DLK1, GTL2, PEG11, antiPEG11, and $M E G 8$ is altered in a genotype- and muscle-specific manner [5, 13]. Specifically, the expression levels of these genes are increased in longissimus muscle from 8-week-old individuals when the $C L P G$ mutation is inherited in $c i s$, yet these genes maintain their exclusive expression from either the paternal or maternal allele [13]. Thus, we have hypothesized that the $S N P^{C L P G}$ position is located within a long-range regulatory element that functions in cis to coordinately control gene expression in the region [21]. This regulatory element is also thought to function in an age-dependent manner because the expression of genes in the cluster is normally downregulated postnatally in sheep skeletal muscle [16]. In addition, the expression of these genes appears to be limited to the callipyge-expressing muscles of the hindquarters, because little expression of DLK1, GTL2, PEG11, antiPEG11, or MEG8 is detected in the supraspinatus (shoulder) muscle [6]. Two additional paternally expressed, protein-coding genes flank this core gene cluster (namely, BEGAIN on the proximal side and $D I O 3$ on the distal side), but their expression is not altered by the $C L P G$ mutation [54].

The presence versus absence of the $C L P G$ mutation on the maternal versus paternal alleles results in a unique expression profile of genes in the DLK1GTL2 cluster for animals of each $C L P G$ genotype (Fig. 1). The phenotypic manifestation of callipyge is likely to depend on this unique expression profile. In other words, the callipyge muscle hypertrophy phenotype is postulated to arise exclusively in animals with the $+^{M} / C L P G^{P}$ genotype because they exhibit an overexpression of the paternally expressed $D L K 1$ and $P E G 11$ genes but not an overexpression of the maternally expressed GTL2, antiPEG11, and $M E G 8$ genes. In contrast, the other three genotypes $\left(+^{M} /+^{P}, C L P G^{M} /+^{P}\right.$, and $C L P G^{M} / C L P G^{P}$ ), which exhibit alternative expression profiles of these genes, do not develop the callipyge phenotype. 


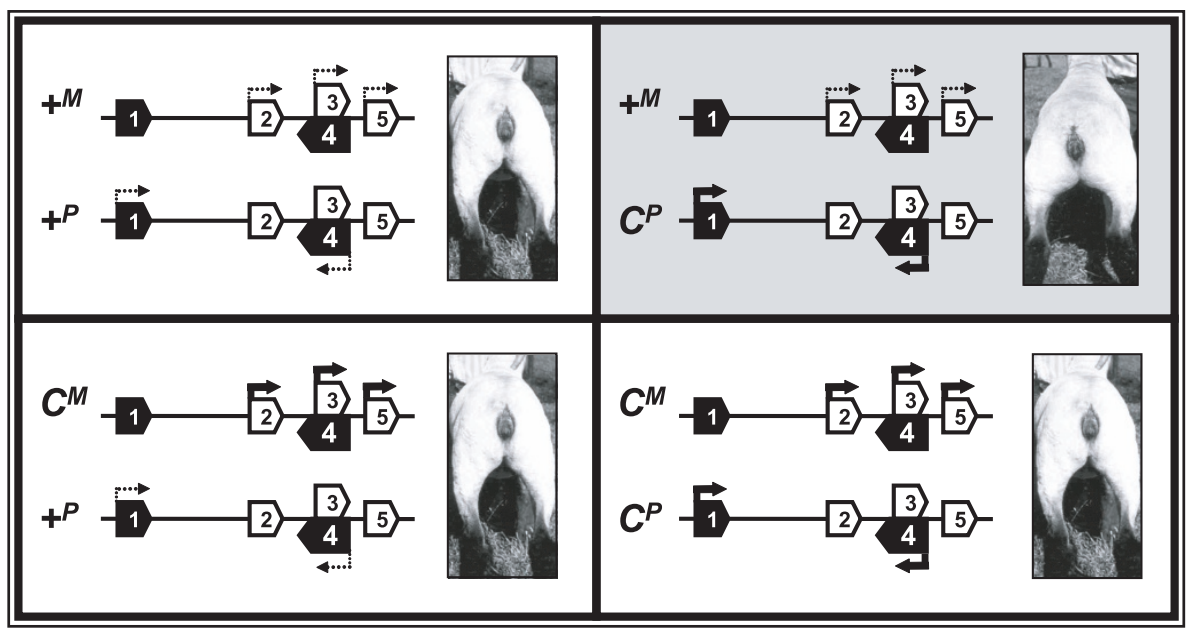

Figure 1. The expression profile of genes in the DLK1-GTL2 cluster for animals of each of the four callipyge genotypes. Each of the five genes whose expression is known to be altered by the $C L P G$ mutation is represented $(1=D L K 1 ; 2=G T L 2$; $3=$ antiPEG $11 ; 4=P E G 11 ; 5=M E G 8)$ by a black or white box to indicate exclusive expression from the paternal $(\mathrm{P})$ or maternal $(\mathrm{M})$ chromosome, respectively. The presence of the callipyge $(C)$ mutation results in enhanced expression of multiple genes in the cluster, depending on its maternal versus paternal inheritance, and this increase in transcript abundance for each gene is depicted by a thick arrow. The only genotype that exhibits the callipyge phenotype is shaded in gray.

Because of the observed CLPG genotype-dependent expression profile of genes in the DLK1-GTL2 imprinted domain, we have predicted that the molecular mechanism of polar overdominance at the CLPG locus results from (1) a cis-effect of the CLPG mutation on the expression levels of genes in the DLK1-GTL2 cluster and (2) a post-transcriptional trans interaction between the products of reciprocally imprinted genes [21]. The candidate effector molecules for muscle hypertrophy development in animals of the $+{ }^{M} / C L P G^{P}$ genotype are the protein products of the paternally expressed $D L K 1$ and $P E G 11$ genes. The effect of DLK1 and/or PEG11 overexpression is effectively silenced in animals of the $C L P G^{M} / C L P G^{P}$ genotype because there is a corresponding overexpression of the maternally expressed genes (GTL2, antiPEG11, and MEG8). The other two genotypes $\left(+^{M} /+^{P}\right.$ and $\left.C L P G^{M} /+^{P}\right)$ do not exhibit an overexpression of the putative protein-coding effectors and therefore, do not exhibit the callipyge phenotype. The possibility of a 
post-transcriptional trans interaction between the products of the paternally expressed effector (DLK1 or PEG11) and the maternally expressed silencer (GTL2, antiPEG11, or MEG8) is currently being tested.

Involvement of the DLK1 and/or PEG11 gene in callipyge muscular hypertrophy is only speculative at this point; neither the $D L K 1$ nor the PEG11 genes has been conclusively shown to be involved in muscle growth. The $D L K 1$ gene encodes a member of the delta-notch family of signalling molecules [33], and the PEG11 gene encodes for a protein product with similarity to the gag and pol polyproteins of retrotransposons [14]. Two lines of evidence currently point towards the involvement of DLK1 in muscle development. First, the dlk protein (encoded by $D L K 1$ ) belongs to a family of signaling molecules involved in the process of differentiation during development in multiple cell lineages, and some of these family members have been shown to inhibit myoblast differentiation in vivo $[17,23]$. Second, relatives of $d l k 1$ have been implicated in anterior-posterior axis formation during development (reviewed in [48]), and DLK1 expression is more pronounced in muscles of the hindquarters as compared to shoulder muscles [6]. Studies are ongoing to determine the involvement of $D L K 1$ and/or PEG11 in producing the callipyge muscle hypertrophy phenotype.

\subsection{The rib-eye muscling (REM) locus}

Interestingly, another locus that affects the longissimus muscle in sheep has been localized to the distal end of OAR18 near CLPG [47]. In the late 1980's, Australian Poll Dorset rams possessing unusually large rib-eye (longissimus dorsi) areas were identified at the Carwell Stud, New South Wales, Australia [2]. Accordingly, the locus that is responsible for this hypermuscling phenotype is commonly known as "Carwell," although it has been provisionally designated as the rib-eye muscling (REM) locus (http://www.thearkdb.org, as consulted on 6 July 2004).

In contrast to CLPG, the effect of Carwell is limited to the longissimus muscle, with no effect on fat depth, live weight, or hindquarter weight [40]. Carwell increases the rib-eye area and weight by approximately $11 \%$ and $7 \%$, respectively [41], which translates into a $15 \%$ boost in yield for higher-priced cuts [47]. The Carwell allele does not affect meat tenderness, does not alter intra-muscular fat deposition, and acts as a completely dominant mutation, 
with no parent-of-origin effects on expression [29]. However, Carwell appears to exert sire-dependent effects in the progeny, which are presumably caused by epistatic interactions with an unknown modifier locus [47].

The REM locus has been mapped to the telomeric side of microsatellite marker CSSM18 [47], near the CLPG map position, but its precise position remains poorly defined. Interestingly, a QTL for muscle growth that corresponds to the position of the REM locus on OAR18 was recently reported in British Texel sheep, suggesting that the Carwell allele is also segregating in the UK flock [61-63]. Efforts are currently underway to fine-map the region and to identify the causative mutation for the Carwell phenotype [42, 61]. Further characterization of Carwell will allow researchers to examine its relationship, if any, to callipyge.

\subsection{QTL on OAR2 for Texel double muscling}

Some animals of the Texel breed [64] are characterized by a generalized muscular hyper-development that is reminiscent of the double muscling phenotype in cattle; thus, this Texel hyper-muscling phenotype is commonly known as "Texel double muscling." Studies on Texel sheep in Belgium [12], Australia [39], and New Zealand [8] have indicated the presence of major genes for increased muscling segregating in these flocks. On a histological level, muscles from Belgian Texel double-muscled animals have larger fiber diameters with higher frequencies of type-II fibers [12], indicating that Texel hyper-muscling is due to myocyte hypertrophy. Texels are utilized extensively as a terminal sire breed because of their exceptional conformation and potential to produce higher-yielding carcasses with increased lean and decreased fat content [34].

Mutations in the myostatin (MSTN) gene are known to be responsible for double muscling in cattle (for review, see [1]). Because of the phenotypic similarity between cattle double muscling and Texel double muscling, studies have primarily focused on the possible involvement of MSTN in the generalized muscular hypertrophy that is characteristic of the Texel sheep breed. The entire coding sequence of the ovine MSTN gene has been determined for both double-muscled Belgian Texel animals and normally muscled Romanov controls, but no sequence differences have been found [36]. However, the involvement of MSTN in Texel hyper-muscling cannot be ruled out because a 
functional polymorphism could reside outside of the coding segments of the MSTN gene.

Preliminary results of a whole-genome scan to identify QTL underlying Belgian Texel double muscling showed a major effect of a portion of OAR2 that includes MSTN on muscular development [36-38]. In a separate study, New Zealand scientists reported that the chromosomal region spanning the ovine MSTN locus influenced muscling and fat depth in four of 12 New Zealand Texel sires tested [8]. In addition, UK workers have recently defined two QTL on OAR2, one (at approximately $60 \mathrm{cM}$ ) that affects muscle growth and another (at about $170 \mathrm{cM}$ ) that influences fat growth in UK Texel sheep [62]. The QTL for fat growth on OAR2 corresponds to the region containing MSTN. The involvement of MSTN in fat deposition is plausible given the reduction in adipose tissue observed in myostatin-deficient mice [35,43]. However, despite these reports of association of the MSTN locus with the Texel double muscling phenotype, the causative mutation that influences muscle and fat growth has yet to be identified, and it may lie outside the coding segments of the MSTN gene or in a closely linked gene.

\subsection{Other QTL for carcass composition in sheep}

The UK Sheep Genome Mapping Project (http://www.projects.roslin.ac. uk/sheepmap, as consulted on 6 July 2004) was initiated by the Roslin Institute (Edinburgh, Scotland) to detect QTL and identify genes that underlie growth and carcass composition in sheep and to utilize those findings for the benefit of the UK sheep industry. As part of this project, a candidate region approach was undertaken to detect QTL segregating in the UK Texel and Suffolk populations [62]. In addition to the significant effects described above on OAR2 and OAR18 for Texel double muscling and Carwell, respectively, several other chromosomal regions were identified with significant effects on muscling or fat (Tab. I). While the effects of OAR2 and OAR18 were supported across multiple sires, the other effects were only detected in individual sires. These effects included QTL on OAR1 (near the transferrin gene) and OAR3 (spanning the IGF1 locus) for muscle and fat growth, respectively, in the Suffolk breed. QTL on OAR4 (spanning the leptin gene) and OAR20 (encompassing the $M H C$ locus) were detected for fat growth in the Texel breed. Further characterization of these effects is ongoing [62]. 


\section{CONCLUSIONS}

In summary, nine genes or QTL have been identified as being associated with carcass traits in sheep (Tab. I). The only causative genetic mutation with a large effect on carcass composition that has been characterized to date is the callipyge (CLPG) mutation. Despite the detection of other QTL affecting muscle growth in sheep (namely, Carwell and Texel double muscling), the underlying genes responsible for these phenotypes have not been identified. Further characterization of mutations responsible for muscle hypertrophy in sheep will not only allow producers to incorporate gene-assisted selection (GAS) into their breeding programs, but it will also contribute to our basic understanding of muscle formation.

\section{ACKNOWLEDGEMENTS}

Our work on callipyge has been supported by grants from the "Fonds de la Recherche Fondamental Collective" (\#2.4525.96), "Crédit aux Chercheurs" (\#1.5.134.00) from the "Fonds National de la Recherche Scientifique", "Crédit à la Recherche from the University of Liège", Belgium, the SSTC (\#0135), the USDA/NRI Competitive Grants Program (\#94-04358, \#96-35205, \#98-03455 and \#01-03332), and the Utah Agricultural Experiment Station, Utah State University, Logan, UT. Carole Charlier is "Chercheur Qualifié FNRS".

\section{REFERENCES}

[1] Arnold H., Della-Fera M.A., Baile C.A., Review of myostatin history, physiology, and applications, Int. Arch. Biosci. (2001) 1014-1022.

[2] Banks R., The Meat Elite Project: establishment and achievements of an elite meat sheep nucleus, Proc. Assoc. Adv. Anim. Breed. Genet. 12 (1997) 598-601.

[3] Beermann D.H., Robinson T.F., Hogue D.E., Impact of composition manipulation on lean lamb production in the United States, J. Anim. Sci. 73 (1995) 2493-2502.

[4] Berg E.P., Neary M.K., Forrest J.C., Methodology for identification of lamb carcass composition, Sheep Goat Res. J. 14 (1998) 65-75.

[5] Bidwell C.A., Shay T.L., Georges M., Beever J.E., Berghmans S., Segers K., Charlier C., Cockett N.E., Differential expression of the GTL2 gene within the callipyge region of ovine chromosome 18, Anim. Genet. 32 (2001) 248-256. 
[6] Bidwell C.A., Shay T.L., Charlier C., Segers K., Georges M., Cockett N.E., Expression of PEG11 transcripts in the muscles of normal and callipyge lambs (Ovis aries), in: Proceedings from the 28th Conference of the International Society of Animal Genetics, 11-15 August 2002, Göttingen, Germany, Poster C004.

[7] Bradford G.E., Selection for reproductive efficiency, Sheep Goat Res. J. 17 (2002) 6-10.

[8] Broad T.E., Glass B.C., Greer G.J., Robertson T.M., Bain W.E., Lord E.A., McEwan J.C., Search for a locus near to myostatin that increases muscling in Texel sheep in New Zealand, Proceedings of the New Zealand Society of Animal Production 60 (2000) 110-112.

[9] Busboom J.R., Wahl T.I., Snowder G.D., Economics of callipyge lamb production, J. Anim. Sci 77 (Suppl. 2) (1999) 243-248.

[10] Carpenter C.E., Rice O.D., Cockett N.E., Snowder G.D., Histology and composition of muscles from normal and callipyge lambs, J. Anim. Sci. 74 (1996) 388-393.

[11] Carpenter C.E., Cockett N.E., Histology of longissimus muscle from 2-weekold and 8-week-old normal and callipyge lambs, Can. J. Anim. Sci. 80 (2000) 511-514.

[12] Charlier C., Leroy P.L., Comparison of muscular fibers of double-muscled Texel and Bleu du Maine, in: Proceedings of the 47th Annual Meeting of the European Association for Animal Production, 25-29 August 1996, Lillehammer, Norway, Session S3.20.

[13] Charlier C., Segers K., Karim L., Shay T., Gyapay G., Cockett N., Georges M., The callipyge (CLPG) mutation enhances the expression of coregulated imprinted genes in cis without affecting their imprinting status, Nat. Genet. 27 (2001) 367-369.

[14] Charlier C., Segers K., Wagenaar D., Karim L., Berghmans S., Jaillon O., Shay T., Weissenbach J., Cockett N., Gyapay G., Georges M., Human-ovine comparative sequencing of a 250-kb imprinted domain encompassing the callipyge (clpg) gene and identification of six imprinted transcripts: DLK1, DAT, GTL2, PEG11, antiPEG11, and MEG8, Genome Res. 11 (2001) 850-862.

[15] Cockett N.E., Jackson S.P., Shay T.L., Farnir F., Berghmans S., Snowder G.D., Nielsen D., Georges M., Polar overdominance at the ovine callipyge locus, Science 273 (1996) 236-238.

[16] Davis E.E., Harken-Jensen C., Charlier C., Kleim A., Shay T.L., Beisner B., Cockett N.E., Georges M., Extensive DLKI expression profiling substantiates the callipyge polar overdominance model in sheep implicating a trans effect of coregulated imprinted genes in producing the callipyge phenotype, in: Proceedings from the 28th Conference of the International Society of Animal Genetics, 11-15 August 2002, Göttingen, Germany, Poster C009. 
[17] Delfini M.-C., Hirsinger E., Pourquié O., Duprez D., Delta 1-activated Notch inhibits muscle differentiation without affecting Myf5 and Pax3 expression in chick limb myogenesis, Development 127 (2000) 5213-5224.

[18] Field R.A., Whipple G., The relation of slaughter and carcass weights to production and processing efficiency and market acceptability, Sheep Goat Res. J. 14 (1998) 98-105.

[19] Freking B.A., Keele J.W., Beattie C.W., Kappes S.M., Smith T.P.L., Sonstegard T.S., Nielsen M.K., Leymaster K.A., Evaluation of the ovine callipyge locus: I. Relative chromosomal position and gene action, J. Anim. Sci. 76 (1998) 2062-2071.

[20] Freking B.A., Murphy S.K., Wylie A.A., Rhodes S.J., Keele J.W., Leymaster K.A., Smith T.P.L., Identification of the single base change causing the callipyge muscle hypertrophy phenotype, the only known example of polar overdominance in mammals, Genome Res. 12 (2002) 1496-1506.

[21] Georges M., Charlier C., Cockett N., The callipyge locus: evidence for the trans interaction of reciprocally imprinted genes, Trends Genet. 19 (2003) 248-252.

[22] Hernandez A., Fiering S., Martinez E., Galton V.A., St. Germain D., The gene locus encoding iodothyronine deiodinase type 3 (Dio3) is imprinted in the fetus and expresses antisense transcripts, Endocrinology 143 (2002) 4483-4486.

[23] Hirsinger E., Malapert P., Dubrulle J., Delfini M.-C., Duprez D., Henrique D., Ish-Horowicz D., Pourquié O., Notch signalling acts in postmitotic avian myogenic cells to control MyoD activation, Development 128 (2001) 107-116.

[24] Jackson S.P., Green R.D., Miller M.F., Phenotypic characterization of Rambouillet sheep expressing the callipyge gene: I. Inheritance of the condition and production characteristics, J. Anim. Sci. 75 (1997) 14-18.

[25] Jackson S.P., Miller M.F., Green R.D., Phenotypic characterization of Rambouillet sheep expressing the callipyge gene: II. Carcass characteristics and retail yield, J. Anim. Sci. 75 (1997) 125-132.

[26] Jackson S.P., Miller M.F., Green R.D., Phenotypic characterization of Rambouillet sheep expressing the callipyge gene: III. Muscle weights and muscle weight distribution, J. Anim. Sci. 75 (1997) 133-138.

[27] Jeremiah L.E., Tong A.K.W., Gibson L.L., The influence of lamb chronological age, slaughter weight and gender on consumer acceptance, Sheep Goat Res. J. 14 (1998) 206-213.

[28] Jones K.G., Trends in the U.S. sheep industry, Electronic report from the Economic Research Service, United States Department of Agriculture, Agricultural Information Bulletin (AIB) No. 787 (2004) http://www.ers.usda.gov/publications/aib787 [consulted: 6 July 2004]. 
[29] Jopson N.B., Nicoll G.B., Stevenson-Barry J.M., Duncan S., Greer G.J., Bain W.E., Gerard E.M., Glass B.C., Broad T.E., McEwan J.C., Mode of inheritance and effects on meat quality of the rib-eye muscling (REM) QTL in sheep, Proc. Assoc. Adv. Anim. Breed. Genet. 14 (2001) 111-114.

[30] Kidwell M.G., Kidwell J.F., Sved J.A., Hybrid dysgenesis in Drosophila melanogaster: a syndrome of aberrant traits including mutation, sterility, and male recombination, Genetics 86 (1977) 813-833.

[31] Kobayashi S., Wagatsuma H., Ono R., Ichikawa H., Yamazaki M., Tashiro H., Aisaka K., Miyoshi N., Kohda T., Ogura A., Ohki M., Kaneko-Ishino T., Ishino F., Mouse Peg9/Dlk1 and human PEG9/DLK1 are paternally expressed imprinted genes closely located to the maternally expressed imprinted genes: mouse Meg3/Gtl2 and human MEG3, Genes Cells 5 (2000) 1029-1037.

[32] Koohmaraie M., Shackelford S.D., Wheeler T.L., Lonergan S.M., Doumit M.E., A muscle hypertrophy condition in lamb (callipyge): characterization of effects on muscle growth and meat quality traits, J. Anim. Sci. 73 (1995) 3596-3607.

[33] Laborda J., The role of the epidermal growth factor-like protein dlk in cell differentiation, Histol. Histopathol. 15 (2000) 119-129.

[34] Leymaster K.A., Jenkins T.G., Comparison of Texel- and Suffolk-sired crossbred lambs for survival, growth, and compositional traits, J. Anim. Sci. 71 (1993) 859-869.

[35] Lin J., Arnold H.B., Della-Fera M.A., Azain M.J., Hartzell D.L., Baile C.A., Myostatin knockout in mice increases myogenesis and decreases adipogenesis, Biochem. Biophys. Res. Commun. 291 (2002) 701-706.

[36] Marcq F., Elsen J.M., El Barkouki S., Bouix J., Eychenne F., Grobet L., Karim L., Laville E., Nezer C., Royo L., Sayd T., Bibé B., Leroy P.L., Georges M., Investigating the role of myostatin in the determinism of double muscling characterizing Belgian Texel sheep, Anim. Genet. 29 (Suppl. 1) (1998) 52.

[37] Marcq F., Elsen J.M., Marot V., Bouix J., Coppieters W., Eychenne F., Laville E., Nezer C., Sayd T., Bibé B., Georges M., Leroy P.L., Mapping quantitative trait loci causing the muscular hypertrophy of Belgian Texel sheep, in: Proceedings of the 50th Annual Meeting of the European Association for Animal Production, 22-26 August 1999, Zürich, Switzerland.

[38] Marcq F., Larzul C., Marot V., Bouix J., Eychenne F., Laville E., Bibé B., Leroy P.L., Georges M., Elsen J.M., Preliminary results of a whole-genome scan targeting QTL for carcass traits in a Texel $\times$ Romanov intercross, in: Proc. 7th World Cong. Genet. Appl. Livest. Prod., Montpellier, 19-23 August 2002, Inra, Castanet-Tolosan, France, Abstract 02-14. 
[39] Marshall K., Henshall J., Banks R.G., Van der Werf J., Finding major gene effects in Australian meat sheep - feasibility study for a Texel dataset, Proc. Assoc. Adv. Anim. Breed. Genet. 13 (1999) 86-89.

[40] McEwan J.C., Gerard E.M., Jopson N.B., Nicoll G.B., Greer G.J., Dodds K.G., Bain W.E., Burkin H.R., Lord E.A., Broad T.E., Localization of a QTL for rib-eye muscling on OAR18, Anim. Genet. 29 (Suppl. 1) (1998) 66.

[41] McEwan J.C., Broad T.E., Jopson N.B., Robertson T.M., Glass B.C., Burkin H.B., Gerard E.M., Lord E.A., Greer G.J., Bain W.E., Nicoll G.B., Ribeye muscling (REM) locus in sheep: phenotypic effects and comparative genome localization, in: Proceedings of the 27th Conference of the International Society of Animal Genetics, 22-26 July 2000, Minneapolis, MN, USA, Poster B011.

[42] McLaren R.J., Broad T.E., McEwan J.C., Jopson N.B., Robertson T.R., Glass B.C., Gerard E.M., Greer G.J., Bain W.E., Nicoll G.B., Identification of positional candidates for the Carwell locus for rib-eye muscling in sheep, in: Plant and Animal Genome IX, 13-17 January 2001, San Diego, CA, USA, W46.

[43] McPherron A.C., Lee S.J., Suppression of body fat accumulation in myostatindeficient mice, J. Clin. Invest. 109 (2002) 595-601.

[44] Miyoshi N., Wagatsuma H., Wakana S., Shiroishi T., Nomura M., Aisaka K., Kohda T., Surani M.A., Kaneko-Ishino T., Ishino F., Identification of an imprinted gene, Meg3/Gtl2 and its human homologue MEG3, first mapped on mouse distal chromosome 12 and human chromosome 14q, Genes Cells 5 (2000) 211-220.

[45] Montgomery G.W., Galloway S.M., Davis G.H., McNatty K.P., Genes controlling ovulation rate in sheep, Reproduction 121 (2001) 843-852.

[46] Moore S.W., Field R.A., Riley M.L., Russell W.C., Consumer evaluation of cuts from normal and callipyge lambs, Sheep Goat Res. J. 14 (1998) 202-205.

[47] Nicoll G.B., Burkin H.R., Broad T.E., Jopson N.B., Greer G.J., Bain W.E., Wright C.S., Dodds K.G., Fennessy P.F., McEwan J.C., Genetic linkage of microsatellite markers to the Carwell locus for rib-eye muscling in sheep, in: Proc. 6th World Cong. Genet. Appl. Livest. Prod., 11-16 January 1998, Vol. 26, University of New England, Armidale, NSW, Australia, pp. 529-532.

[48] Rida P.C.G., Minh N.L., Jiang Y.-J., A Notch feeling of somite segmentation and beyond, Dev. Biol. 265 (2004) 2-22.

[49] Schmidt J., Matteson P.G., Jones B.K., Guan X.-J., Tilghman S.M., The Dlkl and Gtl2 genes are linked and reciprocally imprinted, Genes Dev. 14 (2000) 1997-2002.

[50] Seitz H., Youngson N., Lin S.-P., Dalbert S., Paulsen M., Bachellerie J.P., Ferguson-Smith A.C., Cavaillé J., Imprinted microRNA genes transcribed antisense to a reciprocally imprinted retrotransposon-like gene, Nat. Genet. 34 (2003) 261-262. 
[51] Shackelford S.D., Wheeler T.L., Koohmaraie M., Effect of the callipyge phenotype and cooking method on tenderness of several major lamb muscles, J. Anim. Sci. 75 (1997) 2100-2105.

[52] Sillence M.N., Technologies for the control of fat and lean deposition in livestock, Vet. J. 167 (2004) 242-257.

[53] Smit M.A., Segers K., Carrascosa L.G., Shay T.L., Baraldi F., Gyapay G., Snowder G., Georges M., Cockett N., Charlier C., Mosaicism of Solid Gold supports the causality of a noncoding A-to-G transition in the determinism of the callipyge phenotype, Genetics 163 (2003) 453-456.

[54] Smit M.A., Long-range transcriptional regulation at the ovine callipyge imprinted gene cluster, Ph.D. Dissertation, Utah State University, Department of Animal, Dairy Vet. Sci., 2004.

[55] Takada S., Tevendale M., Baker J., Georgiades P., Campbell E., Freeman T., Johnson M.H., Paulsen M., Fergson-Smith A.C., Delta-like and Gtl2 are reciprocally expressed, differentially methylated linked imprinted genes on mouse chromosome 12, Curr. Biol. 10 (2000) 1135-1138.

[56] Tatum J.D., Savell J.W., Cross H.R., Butler J.G., A national survey of lamb carcass cutability traits, SID Res. J. 5 (1989) 23.

[57] Thompson J.M., Ball A.J., Genetics of meat quality, in: Piper L., Ruvinsky A. (Eds.), The Genetics of Sheep, CAB International, Wallingford, 1997, pp. 523-538.

[58] Tomita T., One-side cross sterility between inbred strains of mice, Jpn. J. Genet. 35 (1960) 291.

[59] Tsai C.-E., Lin S.-P., Ito M., Takagi N., Takada S., Ferguson-Smith A.C., Genomic imprinting contributes to thyroid hormone metabolism in the mouse embryo, Curr. Biol. 12 (2002) 1221-1226.

[60] Waldron D.F., Strategies for genetic improvement of carcass value in lambs, Sheep Goat Res. J. 17 (2002) 33-37.

[61] Walling G.A., Visscher P.M., Simm G., Bishop S.C., Confirmed linkage for QTLs affecting muscling in Texel sheep on chromosomes 2 and 18, in: Proceedings of the 52nd Annual Meeting of the European Association for Animal Production, 26-29 August 2001, Budapest, Hungary, Paper G5.6.

[62] Walling G.A., Wilson A.D., McTeir B.L., Visscher P.M., Simm G., Bishop S.C., A candidate region approach allows efficient QTL detection in UK Suffolk and Texel populations, in: Proc. 7th World Cong. Genet. Appl. Livest. Prod., Montpellier, 19-23 August 2002, Inra, Castanet-Tolosan, France, Abstract 02-16. 
[63] Walling G.A., Wilson A.D., McTeir B.L., Visscher P.M., Simm G., Bishop S.C., QTL detection in the UK Suffolk and Texel sheep sire referencing schemes, in: Proceedings of the British Society of Animal Science, April 2002, York, England, p. 22.

[64] Wolf B.T., Jones D.A., Owen M.G., Carcass composition, conformation and muscularity in Texel lambs of different breeding history, sex, and leg shape score, Anim. Sci. 72 (2001) 465-475.

[65] Wylie A.A., Murphy S.K., Orton T.C., Jirtle R.L., Novel imprinted DLK1/GTL2 domain on human chromosome 14 contains motifs that mimic those implicated in IGF2/H19 regulation, Genome Res. 10 (2000) 1711-1718.

[66] Yevtodiyenko A., Carr M.S., Patel N., Schmidt J.V., Analysis of candidate imprinted genes linked to Dlkl-Gtl2 using a congenic mouse line, Mamm. Genome 13 (2002) 633-638.

To access this journal online: www.edpsciences.org 
